CATALAN REVIEW

Catalan Review

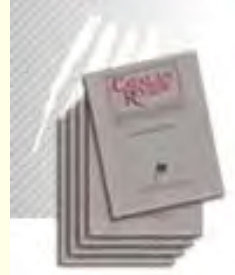

You are accessing the Digital Archive of the Catalan Review Journal.

By accessing and/or using this Digital Archive, you accept and agree to abide by the Terms and Conditions of Use available at http://www.nacs-

catalanstudies.org/catalan_review.html

Catalan Review is the premier international scholarly journal devoted to all aspects of Catalan culture. By Catalan culture is understood all manifestations of intellectual and artistic life produced in the Catalan language or in the geographical areas where Catalan is spoken. Catalan Review has been in publication since 1986 .
NORTH

AMERICAN

CATALAN

SOCIETY
Esteu accedint a l'Arxiu Digital del Catalan Review

A l' accedir i / o utilitzar aquest Arxiu Digital, vostè accepta i es compromet a complir els termes i condicions d'ús disponibles a http://www.nacs-

catalanstudies.org/catalan_review.html

Catalan Review és la primera revista internacional dedicada a tots els aspectes de la cultura catalana. Per la cultura catalana s'entén totes les manifestacions de la vida intel lectual i artística produïda en llengua catalana o en les zones geogràfiques on es parla català. Catalan Review es publica des de 1986.

\title{
Exempla in the Libre de Sancta Maria and Traditional Medieval Marian Miracles David J. Viera
}

Catalan Review, Vol. IV, number 1-2 (1990), p. 221-231 
EXEMPLA IN THE LIBRE DE SANCTA MARIA AND TRADITIONAL MEDIEVAL MARIAN MIRACLES

DAVID J. VIERA

Ramon Llull included throughout his Libre de sancta Maria a series of narratives or exempla, some of which resemble traditional medieval Mary miracles in theme and structure. Martí de Riquer, however, described these narratives as paradigms of anecdotes, which differ from medieval Marian miracles. ${ }^{1}$

I examined eighteen exempla from the Libre de sancta Maria, concentrating on their structure, themes, tone, and Llull's intention in recounting each exemplum. Throughout my analysis I compared these narratives with medieval miracles of Mary to determine their similarities and differences.

In Llull's exempla in which Mary intercedes, Mary's attributes and role vis-à-vis God and sinners parallel those of Mary in traditional miracles. On the other hand, there are major differences: Llull's exempla cannot be traced to Latin or Greek sources. In addition, Llull supplied very little detail regarding place and time. Llull also insisted on making the first and second intention of his ethical system the focus of his exempla, thereby giving these narratives a more intellectual tone than medieval miracles, especially those of folk origin.

The character, virtues, and role of Mary are common among medieval Marian miracles. Benedicta Ward attributed the continued popularity of Mary miracles into the thirteenth and fourteenth centuries to Mary's infinite power and concern for every kind of human need. ${ }^{2}$ She added that, along with her power,

${ }^{2}$ Història de la literatura catalana (Barcelona, Ariel, 1964), I, $255-6$.

${ }^{2}$ Benedicta Ward, Miracles and the Medieval Mind (Philadelphia, U of Pennsylvania P I982), I63. 
Mary became the "Mother of Mercy $»^{3}$ and the mediatrix between God and man.

Mary's character, virtues, and role of mediatrix are common among medieval miracles of Mary and Llull's exempla in which Mary enters. More specifically, Mary's role as mediatrix, her relationship to Christ, the just and sinners, her attributes (e.g. compassion, mercy, justice), and the inspiration of confidence she gives sinners are similar in the miracles and exempla.

Llull organized his Libre de sancta Maria into thirty chapters, each titled according to a different attribute of Mary. In chapter four, "De poder", Llull confirmed Mary's power to interecede between God, the just or sinners. She derived this role from her motherhood of Christ:

...e pot Déu home donar gran bontat, veritat e compliment a justs e a pecadors qui a nostra Dona se clamen e qui d'ella misericòrdia e gràcia esperen. $\mathrm{On}$, com açò sia enaixí, doncs, qui poria consirar com gran poder ha nostra Dona qui pot ésser mare e és mare de Déu home, e quí por fer e donar a justs e a pecadors tot ço que li ve a plaer de Déu home? ${ }^{4}$

Not only Mary's power but also her compassion (pietat) stems from the belief that she was Jesus' mother:

Aquesta és pietat sobre pietat qui sia sens passió e dolor, e que sia aitan gran com era en lo món e havia pietat e dolor de la mort de son fill e de la mort dels pecadors. $\left(O E_{1}, 1223\right)^{5}$

However, more than her compassion for sinners, Mary's mercy and her role as intercessor and advocate between Christ

${ }^{3}$ Ward, 144.

${ }^{4}$ Ramon Llull, Obres essencials (Barcelona, Selecta, 1957), I, II70. Further references to this edition will appear in the text.

s On the origin and character of Mary's pity, see José Vidal Vendrell, «La mediación universal en la mariología lulianax. Estudios franciscanos s2 (1951), 23-4. 
and sinners in Llull's Marian exempla parallel these themes in collections of medieval Mary miracles. ${ }^{6}$

In each chapter of the Libre de sancta Maria, Llull reminded the reader of Mary's mercy and/or compassion for sinners. $\mathrm{He}$ believed that her mercy put her above all men and allowed her to intercede between God and the sinner. Given the important role of mercy in Marian miracles, it is not surprising that Llull's chapter on mercy contains more exempla of Mary's help to sinners than any of the thirthy chapters.

Compilers or writers of traditional Marian miracles generally associated justice with God and mercy and compassion with Mary. ${ }^{7}$ Llull also conceded that Mary has compassion for sinners but that she leaves their judgement to Christ:

...car jutjar no és de vostre ofici, ans ho és perdonar e pregar per justs e per pecadors, e per açò sóts assignada a ésser cella que sóts; e leixats a vostre fill jutjar e fer a sa volentat e no us entremetats de son ofici. ( $\left.O E_{1}, 1225\right)$.

Llull, however, attributed both justice and mercy to Mary, insisting that the two must coexist $(O E 1, I 189, I 192)$ and impede despair in the sinner:

la misericòrdia e la pietat de nostra Dona han concordança ab la justícia, e enaixí lo pecador converteix-se de esperança en esperança per ço car membra e entén e ama nostra Dona $(O E$ 1213).

${ }^{6}$ Llull stressed these themes in other works: See Juan M. Casante Dávila, "El culto a María en los escritos del B. Ramon Llull», De cultu mariano saeculis XII-XV. Acta Congressus Mariologici-Mariani Internationalis (Roma, Pontificia Academia Mariana Internationalis, 198I), 5, 78-8I.

7 At times Mary demands justice or recompense from the sinner. This is true in the miracles Francesc Eiximenis took from traditional sources and placed in his Catalan prose: see David J. Viera, «Els miracles de Maria en l'obra catalana de Francesc Eiximenis», Actes del Quart Col-loqui d'Estudis Catalans a NordAmèrica (Montserrat, 1985), 4, 122-30. 
However, Mary's justice must correspond to God's justice. In addition, the Christian looks upon Mary as the Mother of Mercy rather than the Mother of Justice ( $O E_{1}$, I I69).

Analogous to justice is Mary's role in granting grace to sinners, which Llull included in his chapter, "De gràcia». Here the author took up the "Gratia Plena» theme of Blaquerna and introduced several exempla, some on Mary's role as intercessor. The sinner receives grace from Mary, who in turn derives grace from God. ${ }^{8}$ However, this belief is a departure from some early Marian legends in which the grace of sorrow for sin comes directly from Christ. ${ }^{9}$

Although Mary appears in a dream to one sinner $(O E$ I, I199), a motif in traditional Mary miracles, she plays a minimal and sometimes ambiguous role is some of Llull's exempla. In the exemplum of the highbred soldier who repented and placed his estate in a bishop's hands to care fot the poor, Llull mentioned Mary only once: «aquell cavaller pregà nostra Dona que li perdonàs» $\left(O E_{\mathrm{I}}, \mathrm{I}\right.$ 233). Llull made no further mention of Mary but continued this more detailed exemplum to describe how future bishops distributed the noble's wealth to their clergy and not to the poor out of love for God (first intention). Also, in another exemplum, one in which Hope appears, it is not clear whether this allegorical figure represents Mary or a messenger from God or Mary $\left(O E_{1}, 1216\right)$.

In many popular medieval miracles of Mary, she aids a persons who had been devoted to her and later sinned. This aid takes the form of a miracle in which Mary saves the sinner's soul from damnation, cures physical problems, resurrects sinners from the dead or replaces the sinner in their daily lives. In these miracles the actual mention of repentance is omitted. Llull did not narrate

${ }^{8}$ Vidal Vendrell, $31-3$.

9 Mary Vicentine Gripkey, The Blessed Virgin Mary as Mediatrix in Latin and Old French Legend Prior to the Fourteenth Century (Washington, Catholic $\mathrm{U}$ of America P, 1938), 210-I. 
these types of miracles in the Libre de sancta Maria because his motive was that sinners realize the first intention and repent before Mary.

Benedicta Ward enumerated several characteristics of early Marian miracles. Some miracles took place at shrines. Compilers gathered these local miracles into collections, often combining them with general miracles. The earliest compilations, which date from the twelfth century, fall into three groups of universal interest: knights, young lovers, and sinners. Also, miracles were often the result of events or connected with certain feasts. ${ }^{10}$

In medieval Catalan literature, Marian miracles appear in two major compilations: Recull d'eximpis e miracles ${ }^{11}$ and the Miracles de la Verge Maria. ${ }^{\mathrm{I2}}$ However, in the thirteenth to the fifteenth century, authors such as Llull, Francesc Eiximenis, and Vincent Ferrer interspersed their moral-didactic prose and sermons with Mary miracles.

Llull was no doubt familiar with the corpus of Marian miracles from the twelfth century. Also, in Blaquerna he described a miracle of Mary, whose themes and development are similar to those of Alfonso $\mathrm{X}$ and other writers, although the Catalan author did not rely on a specific source. I refer here to the anecdote of the farmer who had faith in the "Gratia Plena» and received from Mary enough corn for the local monastery to share with the poor $(O E \mathrm{I}, 200-\mathrm{I})$. The narrative development, use of a place and time, and apparent miracle (Mary continued filling the farmer's granary with corn) recall traditional Marian miracles by such authors as Vincent de Beauvais, Gautier de Coincy, Jean Herolt, Gil de Zamora, and others who compiled popular miracles in which the just were rewarded because of their confidence and worship of Mary. Also, although Llull narrated this miracle

${ }^{10}$ Ward, $132-65$.

${ }^{I r}$ Ed. Marià Aguiló (Barcelona, Biblioteca Catalana, 1881-82).

${ }^{12}$ Ed. Pere Bohigas (Barcelona, Biblioteca Catalana d'Obres Antigues, 1956). 
in Blaquerna with the same intention he had when he wrote the Libre de sancta Maria (i.e. to emphasize Mary's grace), there are significant differences between the miracle and the exempla of the latter work as I point out when I compare the exempla with traditional miracles.

Major diferences exist between Llull's exempla in the Libre de sancta Maria and the popular medieval mirabilis Mariae because of Llull's particular structure, choice of themes, and especially his insistence on a first and second intention. In addition, the exempla are characterized by "temporal vagueness» as Martí de Riquer pointed out, ${ }^{13}$ and lack of spacial references. ${ }^{14}$ Llull did not concern himself with time and place for two reasons: the allegorical nature of the Libre de sancta Maria and the emphasis on first intention. Llull gave his exempla an allegorical structure since allegory characterizes the overall framework of the Libre and distinguishes its exempla from popular medieval miracles. Three of the four participants in the dialog (Ladies Prayer, Praise and Intention) are allegorical figures along with Hope, who appears in one exemplum $\left(O E_{1}, \mathrm{I} 2 \mathrm{I} 6\right)$, a rare device in traditional medieval miracles. Authors or compilers of medieval Marian miracles encouraged devotion to Mary as they taught a moral lesson. Llull had a didactic and devotional purpose in mind when he wrote the Libre de sancta Maria, in addition to a mystical purpose.

E. Allison Peers judjed the Libre de sancta Maria harshly, describing the conversation between allegorical characters as "flat", its figures of speech as "conventional", and the entire book as "not subtle or literary». But he reserved his most severe critism for the exempla, regarding them as «colourless» and "inexpressibly trite», adding:

${ }^{13}$ Riquer, 256.

14 One exemplum in which Mary figures has a more specific time frame and place $\left(O E_{1}, 1233\right)$. 
...one after another of them comes to a dreary end without any point being made at all; to contrast them with the anecdotes of Blanquerna is painful. ...the dead level of their dull respectability makes them even more monotonous. ${ }^{25}$

Peers may have judged Llull's narrative prose according to the novel as it developed after the Middle Ages, especially the nineteenth-century novel, and/or medieval exempla (e.g. traditional Mary miracles). He failed to realize that one can not pass judgment on the Libre de sancta Maria without considering first and foremost the "primer e segona intenció». Llull structured each chapter of this work so that Lady Prayer's impassioned lament about lack of devotion to Mary and Lady Praise's convincing reasons why humankind should honor Mary are brought together and resolved by Lady Intention, who uses exempla to bring forth the first and second intentions. ${ }^{16}$ This statement also implies that the exempla under study here lie at the very heart of each chapter. In this work sinners face a dilemma, and, through Mary's help, realize that their error consists of following the second intention rather than the first. For example, in the chapter on consolation, two adulteresses, one motivated by service, honor and love for Mary (first intention) and the other out of fear that her husband might harm or kill her should he find out about her adultery (second intention) prayed to Mary for aid to abstain from sexual $\sin \left(O E_{1}, 1185\right)$. Mary, in turn, gave grace only to the first woman. In the chapter on obedience, Lady Intention tells about a monk who obeyed his abbot out of the desire for his own salvation $(O E \mathrm{I}, \mathrm{I} 235-6)$. When he was continuously tempted to disobey, he prayed to Mary and then realized that the first intention for his obedience should have been love for God and Mary. Motivated by this first intention, he no longer desired to

Is E. Allison Peers, Ramon Llull; A Biography (London, Society for Promoting Christian Knowledge, 1929), 230-1.

${ }^{16}$ Intention narrates fifteen of the eighteen exempla in which Mary takes part. Of the remaining three, Praise recounts two $\left(O E_{\mathrm{I}}, \mathrm{II}_{192}\right)$ and the hermit one ( $\left.O E_{1}, 1194\right)$. 
disobey his abbot. Lady Intention tells another anecdote about a woman married to a merchant, who spent much time away. When tempted by a handsome, young man, she remained faithful to her husband out of love for him. At a time of crisis, she called upon Mary to help her remain chaste and later marveled at her perseverance in chastity after comprehending that the first intention of her chastity should be her love for Mary. From a general ethical perspective, it would seem noble for a woman to remain faithful to her husband out of love for him. But in Llull's philosophical system of first and second intentions, to choose to act morally out of human of self concern, instead of service, honor, and love of God and Mary (in these exempla), indicates a distorted and evil use of one's free will, and therefore $\sin { }^{17}$

Some of Llull's exempla in the Libre de sancta Maria fall short of actual miracles because the autor is more preoccupied with the sinner realizing the first intention. In the chapter «D'Ajuda", a man who killed his father and committed incest with his mother despaires of God's and Mary's mercy. Only when he learns to love Mary for her virtues and attributes is he pardoned. A reader familiar with a large corpus of medieval Mary miracles often expects a specific outcome because they usually have predictable endings. However, Llull's didactic purpose centers not on revealing whether the sinner was saved but on specifying how the sinner realized the first intention. In his chapter on grace, Mary rewarded with a son a woman who loved chastity for her sake $\left(O E_{1}, 1186\right)$. The son died five years later when the woman committed a carnal sin. The exempla stops here, leaving the reader wondering whether the woman was saved. Llull, however, chose to invert the procedure by which the sinner realized the first and second intentions and left the woman in the state of sin. In the chapter on consolation, a faithful wife accused by an evil man of having sinned with him turned to Mary and received

${ }_{17}$ Tomàs Carreras Artau and Joaquim Carreras Artau, Historia de la filosofía española (Madrid, Bermejo, I943), I, 6 II. 
consolation in Mary's virtues, beginning with humility and hope $(O E$ I, I228). When the defamer confessed that he had falsely accused her, she was received in good faith by family and friends. But she no longer felt as virtuous and sanctified as she did when she consoleed herself in the virtues Mary exemplified. Again the entire anecdote is subordinated to the first intention.

Authors of medieval Mary miracles often narrated anecdotes that include physical cures and the resurrection of the dead. However, Llull mentioned physical cures in only two exempla of the Libre de sancta Maria (OE I, I160-61, 1203). In the first anecdote Mary saved a canon from death when he made up his mind to lead a good life for love of Mary not for his own salvation and spent the rest of his life in devotion to her. ${ }^{18} \mathrm{In}$ another exempla, a queen, whose son might die, subjected her will (that her son live) to Mary's wishes. Her son survived and became a good king. In both anecdotes physical cure took place after the sinner became aware of and followed the first intention.

Yet Llull's insistence on the first intention per se should not be taken as a characteristic distinguishing his exempla from the corpus of medieval Mary miracles. In her evaluation of thirteenth and fourteenth-century Marian miracles, Benedicta Ward wrote: «Only one thing was demanded, devotion to her (Mary) involving repentance for her sake and with her aid ${ }^{19}{ }^{19}$ Therefore, the motive for repentance in both traditional miracles and Llull's exempla was for the sake of the divine, that is, repentance was acceptable only when the sinner followed the will of God. What distinguishes Llull's exempla is that he went a step further by specifying the divine will in terms of first and second intentions.

However, sinners who pray to Mary in Llull's narratives resolve their dilemmas (i.e., become aware of the first intention)

${ }^{18}$ Eiximenis wrote in later years miracles that resemble this exemplum in theme and structure. However, Llull's exemplum lacks the severe tone of Eiximenis's miracle (Viera, 122-30).

19 Ward, 163. 
in a more cerebral way than their counterparts in late medieval Mary miracles. For example, the king who begrudged the Beguin for his sexual sin realized how God must also despise him (the king) for also having sinned with women (OE I, II92-3). He refrained from this sin for Mary's intention and became a just king dedicated to good works.

In his Libre de sancta Maria Llull included two exempla in which a Christian doubts the doctrine of the Virgin Birth. In one case a cleric whose doubt turned to fear, anger, and detachment, called upon Mary. After having paced his hope in her, he submitted his will to his understanding and vice versa for the love of Mary's virginity. As a result he came to believe and obey this doctrine unshakingly. Llull used these exempla to illustrate the essential meaning of intention, which he described philosophically in his Libre de contemplació en Déu: understanding and will unite to bring together what is desired and understood. ${ }^{20}$ The solution to the cleric's temptation (doubt of the dogma) came to him when he discovered the first intention, and intellectual and volitional process. The «miracle» here (casting off temptation to doubt dogma) coincided with the realization of the first intention.

In a similar exemplum, a young girl who doubted Mary's virginity after childbirth lost her «spiritual virginity" (sin of desire) by wanting sex with a holy man who cured her of head aches and an eye disease. When she understood how she lad lost her «spiritual virginity», and not her "physical virginity", she began to realize how Mary could remain a virgin after Christ's birth. After a series of other realizations, Llull revealed that Mary healed the virgin (spiritually) when the girl honored Mary for her spiritual and physical virginity.

Acceptance of Church doctrine also coincides with the first intention in the exemplum of a woman who sometimes felt ill will toward her husband she loved. She then realized that her 
conjugal love should motived by and directed toward procreating children who will love God and serve Mary (first intention) rather than motived by his wealth, youth, and noble lineage (second intention).

In conclusion, although in his exempla Llull gave Mary the same attributes and function as mediatrix found in traditional Marian miracles, he preferred to structure them and select themes so that the first intention or the sinner's consciousness of it would become the focus of each narrative. In addition, unlike thirteenth and fourteenth-century authors of miracles, Llull did not reproduce in a new form Marian miracles recorded in previous centuries in Latin and other languages. His exempla in which Mary inspires confidence and acts out of mercy are literary creations in which Llull placed little narrative detail to emphasize the divine will, which sinners realize through Mary's grace. In other words, Llull subordinated narrative detail and structure to his ethical and didactic purpose.

DAVID J. VIERA Tennessee Technological University 